\title{
Phorbol 12-Myristate 13-Acetate Induced Cell Death of Porcine Peripheral Blood Polymorphonuclear Leucocytes
}

\author{
Kingo Suzuki and Hideo Namiki* \\ Department of Biology, School of Education, Waseda University, Shinjuku-ku, Tokyo 169-0051, Japan
}

Key words: porcine/polymorphonuclear leucocytes/phorbol 12-myristate 13-acetate/cell death/superoxide/apoptosis

\begin{abstract}
Polymorphonuclear leucocytes (PMNs) circulating in mammalian peripheral blood are terminally differentiated cells, and once isolated in serum-free medium, they undergo apoptosis within 1 or 2 days. In this study, we studied the effects of phorbol myristate acetate (PMA) on the viability of porcine PMNs in vitro. PMA is known to suppress apoptosis in many cell types. PMA but not dioctanoyl glycerol (DOG) induced morphological degeneration and cell death within 3 to 5 hours as assessed by light microscopy observation and the MTT viability assay. This occurred despite the fact that DNA fragmentation associated with "spontaneous apoptosis" was not observed. Morphological degeneration and death were not due to the oxidative damage from superoxides or its metabolites produced by polymorphonuclear leucocytes, because PMA and DOG similarly stimulated superoxide production. Several other inactive phorbol derivatives tested did not cause cell death, suggesting that the toxicity of PMA did not result from non-specific effect of the reagent.
\end{abstract}

Polymorphonuclear leucocytes (PMNs) from mammalian peripheral blood are terminally differentiated cells that spontaneously undergo apoptosis in serum-free culture.

It is widely accepted that protein kinase $C$ plays a key role in regulation of apoptosis, cell survival, and differentiation (1). Phorbol esters, which selectively stimulate protein kinase $\mathrm{C}$ (PKC), block DNA fragmentation and cell death in thymocytes exposed to $\mathrm{Ca}^{2+}$ ionophore or glucocorticoid hormone (2). In U937 cells, DNA fragmentation induced by $\mathrm{C} 2$-ceramide is prevented by phorbol 12-myristate 13-acetate (PMA) (3). With respect to terminal neutrophil differentiation leading to apoptosis, modulation of PKC activity also may be important. For example, during HL-60 cell differentiation into neutrophils, PKC $\alpha$ is specifically down regulated (4). In addition, treatment of human neutrophils with tumor necrosis factor $\alpha$ (TNF $\alpha$ ) results in an increase in concentration of ceramide and its metabolite, shingosine, and it induces apoptosis. This suggests that neutrophil apoptosis in response to TNF $\alpha$ may be related to inhibition of PKC activity (5). In this study, we examined the effects of PKC activators on viability of porcine peripheral blood PMNs suspended in $\mathrm{Ca}^{2+}$, $\mathrm{Mg}^{2+}$ free phosphate buffer under conditions of serum deprivation. Here we report that PMA, but not dioctanoyl glycerol (DOG), induced degenerative changes in cell morphology and cell death within 3 to 5 hours

\footnotetext{
* To whom correspondence should be addressed.

Tel: +81-3-5286-1507, Fax: +81-3-3207-9694
}

without DNA fragmentation.

\section{MATERIALS AND METHODS}

Materials

4- $\beta$-phorbol 12-myristate 13-acetate (PMA), 1,2-dioctanoyl$s n$-glycerol (DOG), $4-\beta$-phorbol 12 -myristate, $4-\beta$-phorbol 13acetate, staurosporine, MTT, sodium-N-lauroylsarcosinate, proteinase $\mathrm{K}$, RNase $\mathrm{A}$ and cytochrome $c$ were puchased from Sigma Chemical Co., USA. Phorbol derivatives including PMA and DOG were dissolved in DMSO $(500 \mu \mathrm{g} / \mathrm{ml})$ and ethanol $(10 \mathrm{mM})$, respectively. Methylcellulose $25 \mathrm{cP}$ and agarose were from Wako Pure Chemical Co., Japan. Ficoll-400 was from Pharmacia Biotech, Japan. The 100 bp DNA ladder marker was from Life Technologies, Japan. All other chemicals were analytical grade.

\section{Isolation of PMNs}

PMNs were isolated from 11 of porcine peripheral blood. Erythrocytes were removed by $0.2 \%$ methylcellulose sedimentation followed by hypotonic lysis. After centrifugation, cells were resuspended in $25 \mathrm{ml}$ of PBSG $\left(\mathrm{Ca}^{2+}\right.$-, $\mathrm{Mg}^{2+}$ - free phosphate buffered saline, $\mathrm{pH} 7.4$, containing $5 \mathrm{mM}$ glucose), layered on the same volume of 5.6\% Ficoll- 400 , and centrifuged. PMNs were recovered from the bottom of the tube and counted using hemocytometer. They were then suspended in ice cold PBSG at $6 \times 10^{7}$ cells $/ \mathrm{ml}$ and used immediately for experiments. Isolated cells were more than $95 \%$ polymorphonuclear leukocytes most of which were neutrophils checked by nuclear staining with $2 \%$ acetate. 


\section{Incubation of cells with various agents}

All incubations were performed at $37^{\circ} \mathrm{C}$ in $1 \mathrm{ml}$ volumes as described below. Cells were plated at $3 \times 10^{6} \mathrm{cell} / \mathrm{ml}$ in PBSG into a $16 \mathrm{~mm}$ flat bottom polystyrene microplate (IWAKI, Japan). Each agent or its solvent was added at various concentrations, and the neutrophils were incubated at different incubation times (see Results).

\section{Cell viability assay}

Cell viability was assessed by the MTT assay. After various incubation times cells were transferred at $3 \times 10^{5}$ cell $/ 100 \mu l$ into a 96-well microplate (CORNING). Ten $\mu \mathrm{l}$ of a $5 \mathrm{mg} / \mathrm{ml}$ MTT stock solution in PBSG was added, and cells were incubated for 6 hours at $37^{\circ} \mathrm{C}$. Finally, the formazan precipitate was eluted by mixing it thoroughly with isopropanol- $\mathrm{HCl}$ containing $0.04 \mathrm{~N} \mathrm{HCl}$. Absorption at $570 \mathrm{~nm}$ minus $630 \mathrm{~nm}$ were determined using a MTP-22 2-wavelength microplate photometer (CORONA ELECTRIC, Japan).

\section{Superoxide production by neutrophils}

Superoxide was measured as the rate of superoxide dismutase-inhibitable reduction of cytochrome $c$. This was determined from the increase of absorbance at $550 \mathrm{~nm}$ using a U3200 spectrophotometer (HITACHI, Japan). The reaction mixture contained $3 \times 10^{6} \mathrm{PMNs} / \mathrm{ml}$ in $\mathrm{PBSG}$ and $50 \mu \mathrm{M}$ cytochrome $c$. After baseline monitoring, PMNs were activated by addition of PMA or DOG at appropriate concentrations, and monitoring was continued.

\section{DNA fragmentation assay}

For DNA analysis, $1.5 \times 10^{6}$ cells were resuspended in $30 \mu \mathrm{l}$ of lysis buffer (50 mM Tris- $\mathrm{HCl}, \mathrm{pH} 7.8,10 \mathrm{mM}$ EDTA, $0.5 \%$ sodium-N-lauroylsarcosinate), then $3 \mu \mathrm{l}$ of $10 \mathrm{mg} / \mathrm{ml}$ RNase A was added and incubated for $30 \mathrm{~min}$ at $55^{\circ} \mathrm{C}$. Three $\mu \mathrm{l}$ of 10 $\mathrm{mg} / \mathrm{ml}$ proteinase $\mathrm{K}$ was added, and the mixture was incubated for 1 hour at $55^{\circ} \mathrm{C}$. DNA samples were loaded into wells of a $2 \%$ agarose gel and electrophoresed in TE buffer (10 mM Tris-HCl, pH 7.5, 1 mM EDTA) using a Mupid electrophoresis apparatus (ADVANCE, Japan). DNA was visualized by staining with ethidium bromide and viewing in ultraviolet light.

\section{Cell morphology}

Cells were mounted on glass slides, and morphology was examined using a DIAPHOTO-TMD phase-contrast microscope. Photographs were taken at a magnification of 200 .

\section{RESULTS}

\section{Spontaneous PMN apoptosis}

PMNs are known to be short-lived in circulation, because they spontaneously undergo apoptosis (6). In this study, we measured the lifespan of porcine PMNs in serum-free condition employed here. PMNs isolated from porcine peripheral blood as described in Materials and
Methods were suspended in ice cold PBSG and immediately used for experiments. As a negative control, PMNs at $3 \times 10^{6} \mathrm{ml}$ in PBSG without $\mathrm{Ca}^{2+}$ and $\mathrm{Mg}^{2+}$ were incubated at $37^{\circ} \mathrm{C}$. Cell shape was normal after 5 hours (see Fig. 6a and b) and 10 hours (data not shown), and cells were viable when tested by trypan blue exclusion. At later times, cell permeability increased progressively (data not shown). Cell viability also was measured by the MTT assay, which reflects mitochondrial function $(7,8)$. The results show that mitochondrial activity persisted for at least 5 hours of incubation (Fig. 1). Although activity in control cells appeared to increase in Fig. 1, this was not reproducible (see Fig. 3). Thereafter, activity decreased time dependently. Finally, DNA fragmentation, known as a characteristic of apoptosis, was assessed. As shown in Fig. 4, DNA fragmentation occurred time dependently (Fig. 4, lanes 2-6).

In many cell types, PMA activates PKC and suppresses apoptotic signals induced by various reagents $(2,3,9)$. Therefore, we next examined the effect of PMA on the cell survival of porcine PMNs isolated in PBSG as described above (see below).

\section{PMA but not DOG induces a rapid decrease in PMN viability}

PMNs were incubated with $100 \mathrm{ng} / \mathrm{ml}$ PMA or $10 \mu \mathrm{M}$ DOG, and cell viability was assessed by the MTT as-

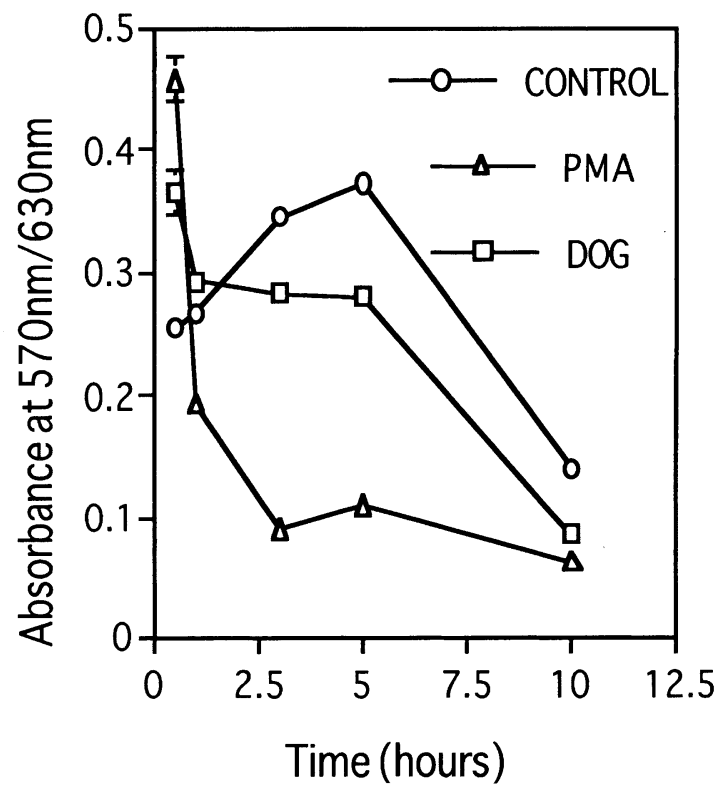

Fig. 1. Viability of PMNs assessed by the MTT assay. $3 \times 10^{6}$ cells $/ \mathrm{ml}$ were incubated for the indicated times at $37^{\circ} \mathrm{C}$ in the absence (open circles) or in the presence of $100 \mathrm{ng} / \mathrm{ml}$ of PMA (open triangles) or $10 \mu \mathrm{M}$ of DOG (open squares). Vertical axis shows absorbance at $570 \mathrm{~nm}$ minus $630 \mathrm{~nm}$ regarded as cell viability. Bars show standard errors $(n=3)$. Almost all the bars were within the symbols. 


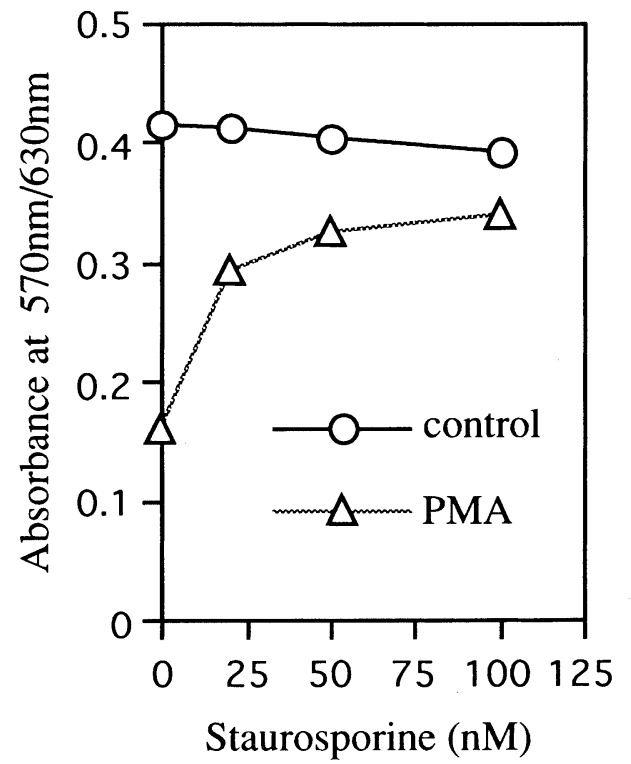

Fig. 2. Staurosporine inhibits PMA-induced cell death. PMNs were incubated with (open triangles) or without (open circles) $100 \mathrm{ng} / \mathrm{ml}$ PMA for 10 hours at $37^{\circ} \mathrm{C}$ after preincubation for an hour with staurosporine at different concentration. Error bars $(n=3)$ were within the symbols.

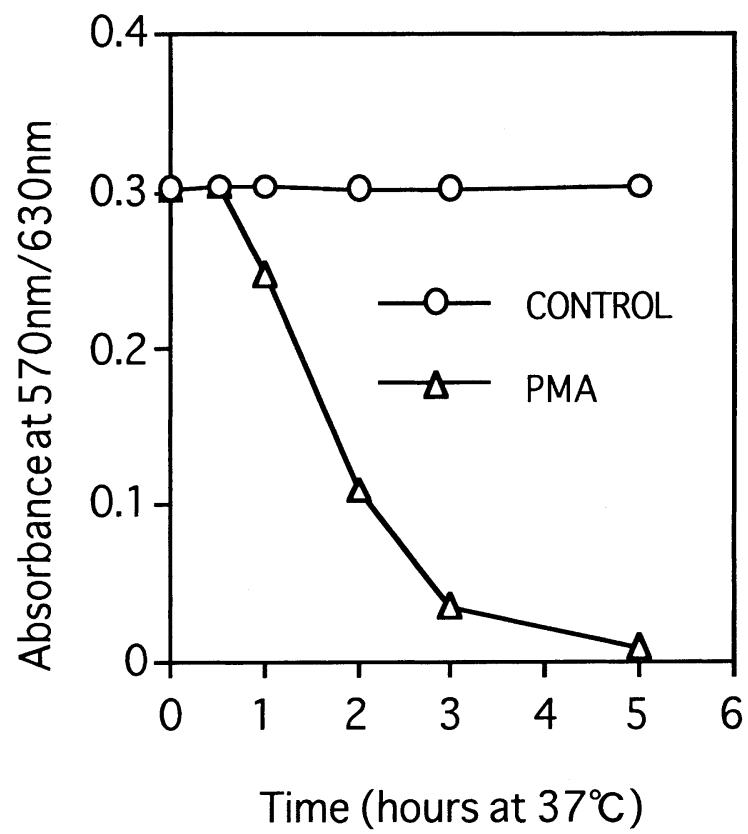

Fig. 3. Effect of temperature shift on PMA-induced reduction of PMN viability. PMNs were incubated in the absence (open circles) or in the presence (open triangles) of $100 \mathrm{ng} / \mathrm{ml}$ of PMA for the indicated times at $37^{\circ} \mathrm{C}$. Plates containing cells were placed immediately on ice and incubation was continued for a total of 5 hours. MTT assay was performed as described. Error bars $(n=3)$ were within the symbols.

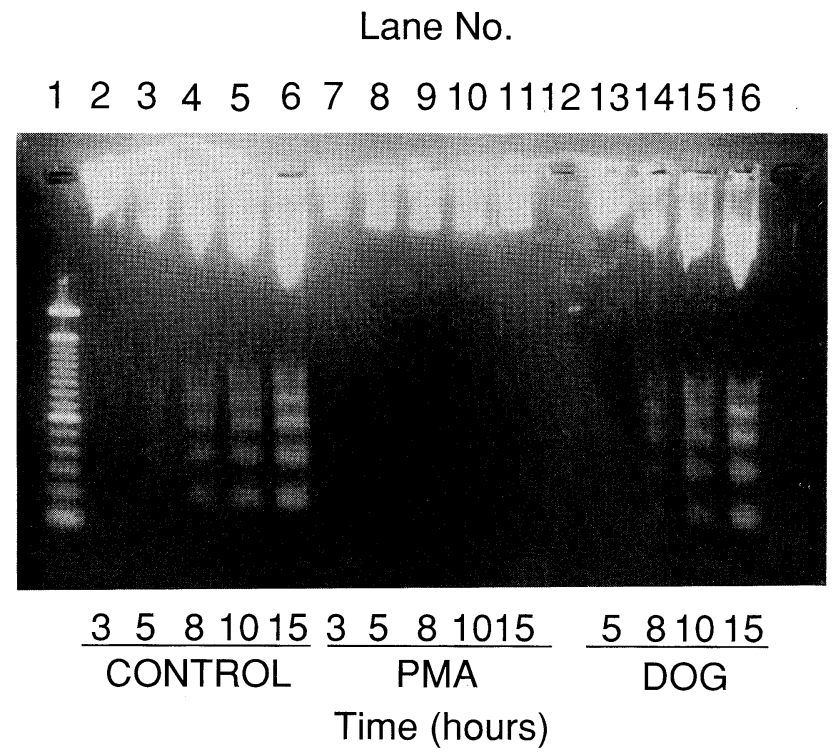

Fig. 4. DNA degradation analysis of PMNs. PMNs were incubated with $100 \mathrm{ng} / \mathrm{ml}$ PMA or $10 \mu \mathrm{M}$ DOG for the indicated times. Aliquots representing $1.5 \times 10^{6}$ cells were processed for DNA analysis and electrophoresed. Control cells were incubated with DMSO.

say. PMA but not DOG rapidly caused decrease of the viability of PMNs (Fig. 1). At the first sampling point at 30 min, PMA treatment increased the absorbance probably reflecting functional activation $(10,11)$. PMA induced cell death at above $1 \mathrm{ng} / \mathrm{ml}$ (data not shown). When PMNs were preincubated with staurosporine, a PKC inhibitor, PMA-induced death was inhibited dose dependently (Fig. 2). This phenomenon was temperature dependent (Fig. 3). At first, PMNs were incubated with PMA at $37^{\circ} \mathrm{C}$ for the indicated times. The cells were then placed on ice immediatedly, and the incubation was continued for a total of 5 hours. PMNs exposed to PMA on ice for 5 hours were as viable as control cells. However, viability decreased in proportion to the incubation time at $37^{\circ} \mathrm{C}$. This indicates that the action of PMA leading to PMN death was temperature dependent.

\section{Effect of PMA and DOG on spontaneous DNA fragmentation}

As shown in Fig. 4, in contrast to control cells undergoing spontaneous DNA fragmentation over time (lanes 2-6), DNA fragmentation was not observed when treated with PMA (lanes 7-11). DOG had little effect on DNA fragmentation (lanes 13-16). Staurosporine inhibited the effect of PMA dose dependently and the cells underwent apoptosis (Fig. 4). Dimethyl sulfoxide and ethanol, the solvents used in this study, had no effect. 


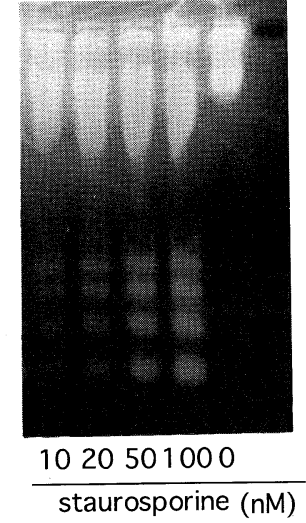

Fig. 5. Staurosporine prevents the effect of PMA on DNA degradation. PMNs were preincubated for 1 hour with staurosporine at different concentrations $(10 \mathrm{nM}, 20 \mathrm{nM}, 50 \mathrm{nM}, 100 \mathrm{nM}$ and $0 \mathrm{nN})$ before 5 hours incubation with PMA. DNA degradation was analyzed as described in Fig. 3. a

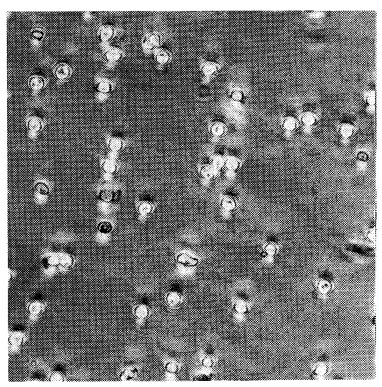

b

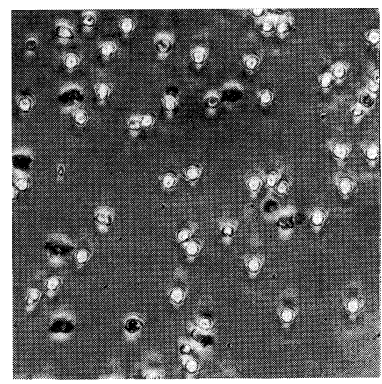

c

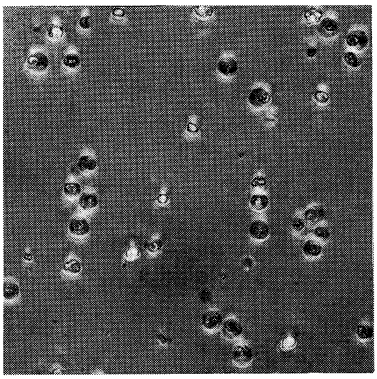

$\mathrm{d}$

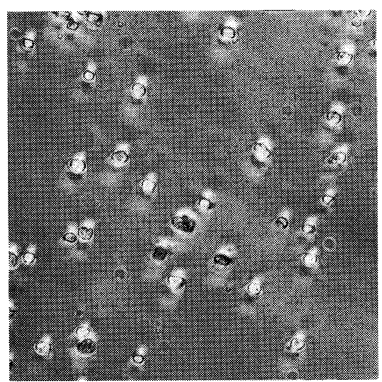

Fig. 6. Morphology of treated PMNs $(200 \times)$. PMNs were incubated in the absence (b) or, in the presence of (c) $100 \mathrm{ng} / \mathrm{ml}$ PMA or (d) $10 \mu \mathrm{M}$ DOG for 5 hours at $37^{\circ} \mathrm{C}$. (a) shows PMNs photographed immediately after isolation from blood.

\section{PMA but not DOG induces degenerative morpho-} logical changes in PMNs

As shown in Fig. 6, incubation of PMNs with $100 \mathrm{ng}$ $/ \mathrm{ml}$ of PMA for 5 hours resulted in morphological degeneration (Fig. 6c) as compared to control cells (Fig. $6 \mathrm{~b})$. Cell volume was increased, and a certain structure was formed in the cell treated with PMA (Fig. 6c).

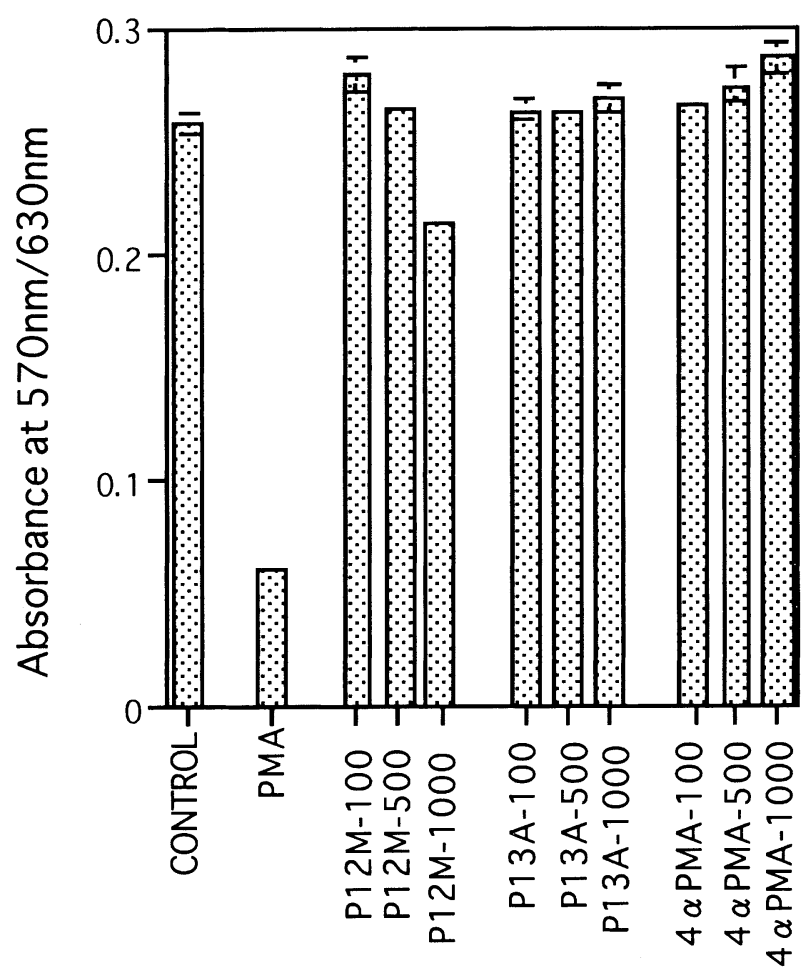

Fig. 7. Cytotoxicity of various phorbol derivatives. PMNs were incubated at $37^{\circ} \mathrm{C}$ for 5 hours in the absence or presence of PMA (100 $\mathrm{ng} / \mathrm{ml})$ or other phorbol derivatives at different concentrations (100 $\mathrm{ng} / \mathrm{ml}, 500 \mathrm{ng} / \mathrm{ml}$ and $1,000 \mathrm{ng} / \mathrm{ml}$ ) as indicated. MTT assay was performed as described. P12M and P13A indicates 4- $\beta$-phorbol 12-myristate and 4- $\beta$-phorbol 13-acetate, respectively. Bars show standard errors $(n=3)$.

PMA was effective at the concentration of $1 \mathrm{ng} / \mathrm{ml}$ and the incubation time of 3 hours (data not shown). Staurosporine inhibited the PMA-induced morphological degeneration (data not shown). On the other hand, when PMNs were treated with $10 \mu \mathrm{M}$ DOG and incubated, morphological changes like those seen in the treatment with PMA did not occur (Fig. 6d).

\section{Inactive phorbol derivatives have no effect on PMN viability and morphology}

Cytotoxicity of various inactive phorbol derivatives also was tested (Fig. 7). Except PMA all of the phorbol derivatives employed were inactive and lacked ability to stimulate PMN superoxide production (data not shown). All the inactive phorbol derivatives had no effect on PMN viability at concentrations up to 1,000 $\mathrm{ng} / \mathrm{ml}$, with the exception that $4-\beta$-phorbol 12-myristate caused a slight decrease in viability at $1,000 \mathrm{ng}$ $/ \mathrm{ml}$. Only PMA induced morphological changes. These results suggest that the toxic effect of PMA did not result from nonspecific effect of the reagent. 


\section{Effects of PMA on morphology and viability of PMNs is not due to superoxides or hydrogen peroxides produced by the activated NADPH oxidase}

In response to various stimuli including PMA and diacylglycerols, PMNs produce superoxides and hydrogen peroxides by activation of the NADPH oxidase (12, 13). Therefore, it is possible that the effects of PMA described above are due to these reactive oxygen species produced by the PMNs. However, this is unlikely for the following reasons: 1) Although both $100 \mathrm{ng} / \mathrm{ml}$ PMA and $10 \mu \mathrm{M}$ DOG stimulated PMN superoxide production to a similar extent (total increase in absorbances at $550 \mathrm{~nm}$ were 0.34 and 0.33 , respectively), DOG had little effect on morphology and viability; 2) Exogenous addition of superoxide dismutase and catalase had only partial effect on the PMA action (MTT assay data were $0.447 \pm 0.008,0.111 \pm 0.006$ and $0.172 \pm 0.002$ for control, PMA in the presence and absence of $500 \mathrm{U}$ $/ \mathrm{ml} \mathrm{SOD}$ and $150 \mathrm{U} / \mathrm{ml}$ catalase, respectively).

\section{DISCUSSION}

Certain phorbol esters including PMA can penetrate cellular membranes and directly activate PKC (14). PKC takes part in cellular responses to various agonists including hormones, neurotransmitters, and some growth factors (1). Consequently, it is widely believed that PKC also has a key role in regulation of apoptosis, cell survival, and differentiation. PMNs are terminally differentiated cells with a short life, because they spontaneously undergo apoptosis. This raised the question whether PMA had an effect on PMN cell survival. In this study, we found that PMA (above $1 \mathrm{ng} / \mathrm{ml}$ ) induced porcine PMN death accompanied by morphological degeneration of cells within 3 to 5 hours, although spontaneous DNA fragmentation was not observed. PMA inhibition of DNA fragmentation is consistent with previous reports $(2,3)$, but the rapid cell death observed in this study was unexpected. The effects of PMA were temperature-dependent (Fig. 3). At low temperature, PMNs neither underwent spontaneous apoptosis nor were killed by exposure to PMA even if incubation was continued for 10 hours (data not shown). Since the inactive phorbol derivatives used in this study were of without effect, it is unlikely that the actions of PMA were due to nonspecific effects.

Robinson et al. $(15,16)$ reported that phorbol esters including PMA that are capable of activating PKC stimulated production of superoxide and changes in ultrastructure of guinea pig neutrophils. Unstimulated neutrophils in suspension are spherical and contain numerous cytoplasmic granules as well as some vesicles (15). When treated with phorbol esters, these cells exhibit a large increase in intracellular vesicles and a decrease in cytoplasmic granules within 5 min of expos- ure (15). At this time the superoxide production is maximal (15). The morphological changes we observed in this study were evident 3 hours after PMA treatment. It is unknown whether this phenomenon was a consequence of the earlier events described above (15). Electron microscopy may be helpful in resolving this issue.

What caused the rapid cell death observed in this study? PMA has been shown to induce cell death in a human prostate cancer cell line, LNCap. Death is preceded by chromatin condensation, nuclear fragmentation and so on, indicative of apoptosis $(17,18)$. The cell death observed in this study was not apoptotic, but was rather necrotic since the PMA-treated cells could not exclude trypan blue dye (data not shown). It is possible that the superoxide and hydrogen peroxide produced by PMA treated PMNs had a direct effect on viability. Inappropriate oxidant production by PMNs in vivo may be of pathological importance in inflammationdependent host tissue damage (19). Moreover, lymphocytes from porcine blood, which hardly produce duperoxide in response to stimuli including PMA (data not shown), showed no morphological changes or cell death (data not shown). However, this possibility was ruled out by the fact that treatment of PMNs with $10 \mu \mathrm{M}$ DOG had little effect on cell viability or morphology (Figs. 1 and 6), although both $100 \mathrm{ng} / \mathrm{ml}$ PMA and 10 $\mu \mathrm{M}$ DOG stimulated PMN superoxide production to a similar extent. In addition, exogenous addition of superoxide dismutase and catalase did not prevent the PMA effect. There is also a possibility that PMA-induced cell death was due to self destructive processes by action of proteases. Preincubation with a mixture of 2 $\mathrm{mM}$ DFP, $10 \mu \mathrm{M}$ PMSF and $10 \mu \mathrm{M}$ leupeptin which itself inhibits degradation of cellular proteins (12) and had no toxicity could not inhibit PMA-induced cell death at all (data not shown). However, the possibility still remains because PMNs possess a variety of proteases required for bactericidal activity.

Both PMA and DOG are known as PKC activators. Diacylglycerols compete directly with phorbol diesters for common binding sites and rapidly activate PKC in HL-60 cells (14) and Swiss 3T3 cells (20). However, PMA but not DOG induced the responses described above. Pretreatment with staurosporine before PMA addition resulted in DNA fragmentation and apoptosis (Fig. 5) indicating that, at least, PKC activation is required for PMA-treated non-apoptotic death. Phorbol esters like PMA are metabolically stable. Thus the cellular responses to these agents seem to differ somewhat from those caused by membrane-permeating diacylglycerols like DOG (1). PKC is known to be down regulated by incubating HL-60 cells with PMA for $3 \mathrm{~h}$ (21). If it is also the case and affect the cell death described in this study it remains to be elucidated.

Further investigations are now in progress to identi- 
fy the molecular basis of PMA effects on PMN morphology and death.

Acknowledgments. We wish to thank Dr. Robert A. Shiurba (Misato Co., Japan) for critical reading of the manuscript.

\section{REFERENCES}

1. NishizUKA, Y. 1992. Intracellular signaling by hydrolysis of phospholipids and activation of protein kinase C. Science, 258: 607-614.

2. McConkey, D.J., Hartzell, P., Jondal, M., and OrRenius, S. 1989. Inhibition of DNA fragmentation in thymocytes and isolated thymocyte nuclei by agents that stimulate protein kinase C. J. Biol. Chem., 264: 13399-13402.

3. OBeid, L.M., Linardic, C.M., KarolaK, L.A., and Hannun, Y.A. 1993. Programmed cell death induced by ceramide. Science, 259: 1769-1771.

4. Devalia, V., Thomas, N.S., Roberts, P.J., Jones, H.M., and LINCH, D.C. 1992. Down-regulation of human protein kinase $\mathrm{C}$ alpha is associated with terminal neutrophil differentiation. Blood, 80: 68-76.

5. Ohta, H., Yatomi, Y., Sweeney, E.A., Hakomori, S., and IGARASHI, Y. 1994. A possible role of sphingosine in induction of apoptosis by tumor nectosis factor-alpha in human neutrophils. FEBS Lett., 355: 267-270.

6. Moulding, D.A., Hart, C.A., and Edwards, S.W. 1996. Modulation of neutrophil apoptosis by pharmacological agents. Biochem. Soc. Trans., 24: 492S.

7. YAKeS, F.M. and Houten, B.D. 1997. Mitochondrial DNA damage is more extensive and persists longer than nuclear DNA damage in human cells following oxidative stress. Proc. Natl. Acad. Sci., 94: 514-519.

8. Kim, Seow W., Thong, Y.H., Nelson, R.D., Macfarlane, G.D., and HerzberG, M.C. 1994. Nicotine-induced release of elastase and eicosanoids by human neutrophils. Inflammation, 18: 119-127.

9. Clement, M.V. and Stamenkovic, I. 1996. Superoxide anion is a natural inhibitor of Fas-mediated cell death. EMBOJ, 15: 216-225.

10. Oez, S., Platzer, E., and Welte, K. 1990. A quantitative colorimetric method to evaluate the functional state of human polymorphonuclear leukocytes. Blut., 60: 97-102.

11. Oez, S., Welte, K., Platzer, E., and Kalden, J.R. 1990. A simple assay for quantifying the inducible adherence of neutrophils. Immunobiology, 180: 308-315.
12. Mizunari, H., Kakinuma, K., Suzuki, K., Namiki, H., Kuratsuji, T., and TsunawaKI, S. 1993. Nucleoside-triphosphate binding of the two cytosolic components of the respiratory burst oxidase system: evidence for its inhibition by the $2^{\prime}, 3^{\prime}$ dialdehyde derivative of NADPH and desensitization in their translocated states. Biochim. Biophys. Acta, 1220: 21-30.

13. Thrasher, A.J., Keep, N.H., WientJes, F., and Segal, A.W. 1994. Chronic granulomatous disease. Biochim. Biophys. Acta, 1227: 1-24.

14. Ebeling, J.G., Vandenbark, G.R., Kuhn, L.J., Ganong, B.R., BeLl, R.M., and NIEDEL, J.E. 1985. Diacylglycerols mimic phorbol diester induction of leukemic cell differentiation. Proc. Natl. Acad. Sci., 82: 815-819.

15. Robinson, J.M., BADWAY, J.A., KARNovsky, M.L., and KARNOvSKY, M.J. 1985. Release of superoxide and change in morphology by neutrophils in response to phorbol esters: antagonism by inhibitors of calcium-binding proteins. J. Cell Biol., 101: 1052-1058.

16. Robinson, J.M., Badway, J.A., Karnovsky, M.L., and KARNOVSKY, M.J. 1987. Cell surface dynamics of neutrophils stimulated with phorbol esters or retinoids. J. Cell Biol., 105: 417-426.

17. Day, M.L., Zhao, X., Wu, S., Swanson, P.E., and HUMPHREY, P.A. 1994. Phorbol esters-induced apoptosis is accompanied by NGF1-A and c-fos activation in androgen-sensitive prostate cancer cells. Cell Growth Differ., 5: 735-741.

18. Young, C.Y., Murtha, P.E., and Zhang, J. 1994. Tumorpromoting phorbol ester-induced cell death and gene expression in a human prostate adenocarcinoma cell line. Oncol. Res., 6: $203-210$

19. Watson, F., Robinson, J., and Edwards, S.W. 1991. Protein kinase C-dependent and -independent activation of the NADPH oxidase of human neutrophils. J. Biol. Chem., 266: 7432-7439.

20. Rozengurt, E., Pena, A.R., Coombs, M., and Smith, J.S. 1984. Diacylglycerol stimulates DNA synthesis and cell division in mouse 3T3 cells: role of $\mathrm{Ca}^{2+}$-sensitive phospholipid-dependent protein kinase. Proc. Natl. Acad. Sci., 81: 5748-5752.

21. Tisch, D., Halpern, M., Marciano, D., Kloog, Y., and AVIRAM, I. 1996. Activation of signaling puthways in HL60 cells and human neutrophils by farnesylthiosalicylate. Eur. $J$. Biochem., 242: 529-536.

(Received for publication, August 5, 1998 and in revised form, October 18, 1998) 